\title{
Knowledge, Attitude and Practices on Cervical Cancer Screening, Prevention, and Control among Undergraduate Female Students in Northwest, Ethiopia: A Descriptive Cross Sectional Study
}

\author{
Alem Getaneh ( $\nabla$ alemgetaneh2@gmail.com ) \\ Birhanemesikel Tegegne \\ University of Gondar College of Medicine and Health Sciences \\ Teshome Belachew \\ University of Gondar College of Medicine and Health Sciences
}

University of Gondar College of Medicine and Health Sciences https://orcid.org/0000-0003-1608-6737

\section{Research}

Keywords: KAP, Cervical cancer, University of Gondar, Ethiopia

Posted Date: November 11th, 2020

DOl: https://doi.org/10.21203/rs.3.rs-102290/v1

License: (c) (1) This work is licensed under a Creative Commons Attribution 4.0 International License.

Read Full License 


\section{Abstract \\ Background}

In the world, cervical cancer is an easily preventable disease and it is one of the leading causes of cancer mortality in females. It is the second most common women cancer in Ethiopia. The aim of the present study was to assess the KAP of undergraduate female students towards cervical cancer screening, prevention, and control.

\section{Methods}

A cross-sectional study was conducted in April 2018 at the University of Gondar, College of Medicine and Health Sciences undergraduate female students. Pretested, self-administered questionnaire was used for data collection. Four hundred and three female students were recruited by a stratified random sampling method and the data were entered and analyzed using SPSS version 20 statistical packages. Descriptive data analysis was used to report the results.

\section{Results}

Most of the respondents (59.3.3\%) had good knowledge, whereas nearly $67.7 \%$ of the respondents had a positive attitude towards cervical cancer. However, less than $1 \%$ of the respondents had been screened for cervical cancer.

\section{Conclusion}

Although female students had a high proportion of good knowledge and a positive attitude, their practices on cervical cancer were quite low. Therefore the university should create awareness on cervical cancer screening, prevention, and control by incorporating in the curriculum.

\section{Introduction}

Cervical cancer is a rapid uncontrolled cell growth and spread at the cervical area (1). Many common human papilloma viruses (HPV) cause this disease. Today, more than 120 different HPV types have been identified. In the world, $80 \%$ of cervical cancer is caused by four high-risk strains (HPV-16, 18, 31, and 45). Females acquire the disease through sexual contact with infected individuals (2). Early-onset of sexual activities, multiple sexual partners, extended use of oral contraceptives, immune-suppression, and smoking (3) are other known risk factors. The spread of diseases is very high among young sexually active adult females, particularly the age of 22-25 years (2). Malignant cervical cancer is characterized by vaginal bleeding, contact bleeding, and vaginal secretion. However, it is one of the most easily 
preventable forms of female cancer. A key aspect of its prevention is the identification of the premalignant form by cervical screening (4).

Lack of knowledge about cervical cancer and risk factors, beliefs about cervical cancer, poor access to preventive services, the supply of the service, and the current health service system were the barriers to the decision to be screened for cervical cancer (5). Cervical cancer is the second most common cancer among women in the developing world and is responsible for the deaths of 230,200 and the new cases of 444,500 annually (6). However, it is largely preventable through early screening, vaccination, early detection, and prompt treatment of detected precancerous lesions, and safe sexual practices (7).

The rate of cervical cancer was five times higher in developing countries (25 per 100000$)$ compared with more developed countries (5 per 100000 ). The high mortality rates are due to the advanced stage at presentation, affected women being unable to complete therapy, lack or unavailability of treatment, and unaffordable therapy(8). The problem is serious in sub-Saharan Africa, 34.8 new cases of cervical cancer were diagnosed per 100,000 women every year, and 22.5 per 100,000 women deaths reported. This is higher compared with 6.6 and 2.5 per 100000 women cases and death in North America, respectively (2).

In Ethiopia, cervical cancer ranks as the most frequent cancer among women. About one-third(33.6\%) of women are estimated to have cervical cancer infection at a given time (9). In 2010, it was estimated that 20.9 million women were at risk of developing cervical cancer in Ethiopia, with an estimated 4,648 and 3,235 annual numbers of new cases and deaths, respectively. Low coverage of cervical cancer screening is a serious problem and a major barrier in reducing the mortality and morbidity in the developing countries(10). Lack of knowledge and poor attitude towards the disease and risk factors can also affect screening practice and development of preventive behavior for cervical cancer.

No previous study was done on the KAP towards cervical cancer screening as well as prevention and control among the University of Gondar, College of Medicine, and Health Sciences undergraduate female students. Therefore, the present study gives an insight into what the university students know and do.

\section{Methods And Materials}

\section{Study area}

The study was conducted at the University of Gondar, College of Medicine, and Health Sciences in Gondar town, northwest Ethiopia. Gondar town is located in northwestern Ethiopia at a latitude of 12"36'North, and longitude of 37"28'East. The University of Gondar is located in the west of the Central Gondar Administrative Zone, which is, 747 kilometers far from Addis Ababa in the Northwest direction(11).

\section{Study design and period}

An institution-based cross-sectional study was conducted at the University of Gondar, College of Medicine, and Health Sciences on April 2018. 
Measurement of knowledge: Participants who have scored greater than or equal mean value from 11 knowledge questions were considered to have good knowledge, and those who had scored less than the mean value was considered to have poor knowledge.

Measurement of attitude: Participants who have scored greater than or equal mean value from 9 attitude questions were considered to have a positive attitude and those who had scored less than the mean value were considered to have a negative attitude.

Measurement of practice: Participants used at least one alternative method of cervical cancer screening/ prevention/control of cervical cancer was considered as good practice with a score of 1, otherwise poor practice as a score of 0 .

\section{Sample size determination}

The required sample size was determined by using the single population proportion formula based on the following assumptions. The proportion of knowledge/attitude was taken from the results of a study done in Mizan Tepi University, Ethiopia, 61\% (12), with 95\% Cl, a-level 5\%, and considered the margin of error $5 \%$. The minimum sample size was calculated based on the following formula:

$\mathrm{n}=\left(\mathrm{Za} /{ }_{2}\right)^{2} \mathrm{P}(1-\mathrm{P}) / \mathrm{d}^{2} ; \mathrm{n}=(1.96)^{2 \star 0.61}(1-0.61) /(0.05)^{2}=367$

Where: $\mathrm{n}$ = sample size

$\mathrm{Z} \mathrm{a} \mathrm{/2=} \mathrm{normal} \mathrm{distribution} \mathrm{value} \mathrm{at} 95 \% \mathrm{Cl}(\mathrm{Z}=1.96)$

$\mathrm{P}=$ the successful proportion of knowledge/attitude $(0.61)$

$d=$ margin of error $(5 \%)$

Therefore, the final sample size after adding $10 \%$ non-response rate was 403 female students.

\section{Sampling technique}

A stratified sampling technique was used to select the participants of the study. The study population was stratified based on the department. Participants were selected from twelve departments of the University of Gondar, College of Medicine and Health Sciences by using simple random sampling methods. The sample size was proportionally allocated for each selected department based on their class size by using the formula: $\mathrm{ni}=\mathrm{n} \times \mathrm{Ni} / \mathrm{N}$

Where $n=$ the total sample size (403); $\mathrm{ni}=$ sample size in each stratum, $\mathrm{Ni}=$ Number of female students in each department; $\mathrm{N}=$ Total number of female students in the study area (1746). 
Using the students' lists obtained from the office of the registrar as a sampling frame, the respondents were selected by a simple random sampling method. The sample size was proportionally allocated by using the above formula for each department.

\section{Data collection}

The data was collected by using a self-administrated questionnaire that contains different items like socio-demographics, knowledge, attitude, practice, and control of cervical cancer screening, prevention, and control. Questionnaires were adapted from different pieces of literature from previous studies. These questions explored the respondent's knowledge, attitude, and practices about cervical cancer, screening, prevention, and control. The questionnaires were translated from English to Amharic for data collection and vice-versa for data entry for ensuring its consistency.

\section{Data quality management}

A pre-test was done on $5 \%$ of the questionnaire to make sure the questionnaire was appropriately structured and to ensure its consistency. Two days of training were given to data collection facilitators and supervisors for improving the data collection process. Close supervision was followed for ensuring the completeness of questionnaires at the time of data collection. Finally, data editing and clearance were done for the proper management of data.

Data management and analysis

Data were entered after encoded the completed questionnaires and analyzed using SPSS version 20 statistical packages. Descriptive data analysis was used to describe the knowledge, attitude, and practice for cervical cancer screening, prevention, and control. The results were presented in mean/ median, standard deviation, texts, and tables.

\section{Results}

\section{Socio-demographic characteristics of participants}

A total of 403 undergraduate female medical and health science students were included in this study. The overall response rate was $100 \%$. Among these, the majority $302(74.90 \%)$ were between the age range 20 24 years followed by $15-19$ years $99(24.6 \%)$ and $25-30$ years $2(0.5 \%)$ with the mean age of $21+1.5$ $( \pm S D)$ years. About $322(79.9 \%)$ of the respondents were orthodox Christian and 256(63.5\%) were Amhara in ethnicity. Regarding marital status, $390(96.8 \%)$ of the respondents were single followed by $11(2.7 \%)$ married, $1(0.2 \%)$ divorced, and $1(0.2 \%)$ separated. About $333(82.6 \%)$ of the respondents came from urban parts of Ethiopia.

\section{Knowledge of the respondents on cervical cancer}


From this study, more than half of the respondents, 239 (59.3\%) had good knowledge, whereas the remaining two-fifth $164(40.7 \%)$ of respondents characterized by poor knowledge.Majority, $363(90 \%)$ of the respondents heard about cervical cancer from different information sources. Among respondents who heard about cervical cancer, 119(32.8\%) got this information from their teachers. Less than one-third, $142(35.2 \%)$ of the respondents knew about the causative agent of cervical cancer. More than half of the respondents, $211(52 \%)$ knew about the sign and symptoms of cervical cancer, whereas $192(47.6 \%)$ of the respondents didn't know. Among respondents who knew the sign and symptoms, 84 (20.8\%) of respondents said that Vaginal foul-smelling discharge is the symptom of the disease whereas, $83(20.6 \%)$ of the respondents reported that irregular vaginal bleeding is the symptom of the disease. However, onethird, $133(33 \%)$ of participants had no idea what factors raise the chance of getting cervical cancer, whereas one-quarter of participants $101(25 \%)$ reported that having multiple sexual partners is a risk factor for the disease. Most of the respondents, 296 (73.4\%), knew as early treatment can cure cervical cancer. Regarding knowledge on vulnerability for the Pap smear test, 195 (48.4\%) of the respondents pointed out that all women $>25$ years should get the Pap smear test (Table1).

Table 1: Distribution of respondents on knowledge about cervical cancer, screening, prevention and control, University of Gondar, Ethiopia, April, $2018(n=403)$ 


\begin{tabular}{|c|c|c|c|}
\hline Variables & Categories & Number & $\begin{array}{l}\text { Percent } \\
(\%)\end{array}$ \\
\hline \multirow[t]{2}{*}{ Have you ever heard about cervical cancer? } & Yes & 363 & 90.1 \\
\hline & No & 40 & 9.9 \\
\hline \multirow[t]{5}{*}{ Where did you learn about cervical cancer? } & Teachers & 119 & 32.8 \\
\hline & News media & 108 & 29.8 \\
\hline & Health institutions & 98 & 27 \\
\hline & Family, friends, neighbors & 30 & 8.3 \\
\hline & Magazine & 8 & 2.2 \\
\hline \multirow[t]{5}{*}{ What is causative agent of cervical cancer? } & Virus & 142 & 35.2 \\
\hline & Bacteria & 54 & 13.4 \\
\hline & Fungi & 20 & 5 \\
\hline & Parasite & 16 & 4 \\
\hline & Don't know & 171 & 42.4 \\
\hline \multirow[t]{5}{*}{$\begin{array}{l}\text { What are the symptoms of carcinoma of } \\
\text { the cervix? }\end{array}$} & $\begin{array}{l}\text { Vaginal foul smelling } \\
\text { discharge }\end{array}$ & 84 & 20.8 \\
\hline & Vaginal irregular bleeding & 83 & 20.6 \\
\hline & Post coital bleeding & 15 & 3.7 \\
\hline & All of the three symptoms & 29 & 7.2 \\
\hline & Don't know & 192 & 47.6 \\
\hline \multirow{6}{*}{$\begin{array}{l}\text { Do you know the } \\
\text { Risk factors for cancer of the cervix? }\end{array}$} & $\begin{array}{l}\text { Having multiple sexual } \\
\text { partners }\end{array}$ & 101 & 25.1 \\
\hline & Human papilloma virus & 63 & 15.6 \\
\hline & Early sexual intercourse & 48 & 11.9 \\
\hline & Cigarette smoking & 11 & 2.7 \\
\hline & All the four risks & 47 & 11.7 \\
\hline & Don't know & 133 & 33 \\
\hline \multirow[t]{4}{*}{$\begin{array}{l}\text { How can a person prevent getting } \\
\text { cancer of the cervix? }\end{array}$} & $\begin{array}{l}\text { Avoid multiple sexual } \\
\text { partners }\end{array}$ & 101 & 25.1 \\
\hline & $\begin{array}{l}\text { Avoid early sexual } \\
\text { intercourse }\end{array}$ & 68 & 16.9 \\
\hline & HPV & 33 & 8.2 \\
\hline & Page $7 / 18$ & & \\
\hline
\end{tabular}




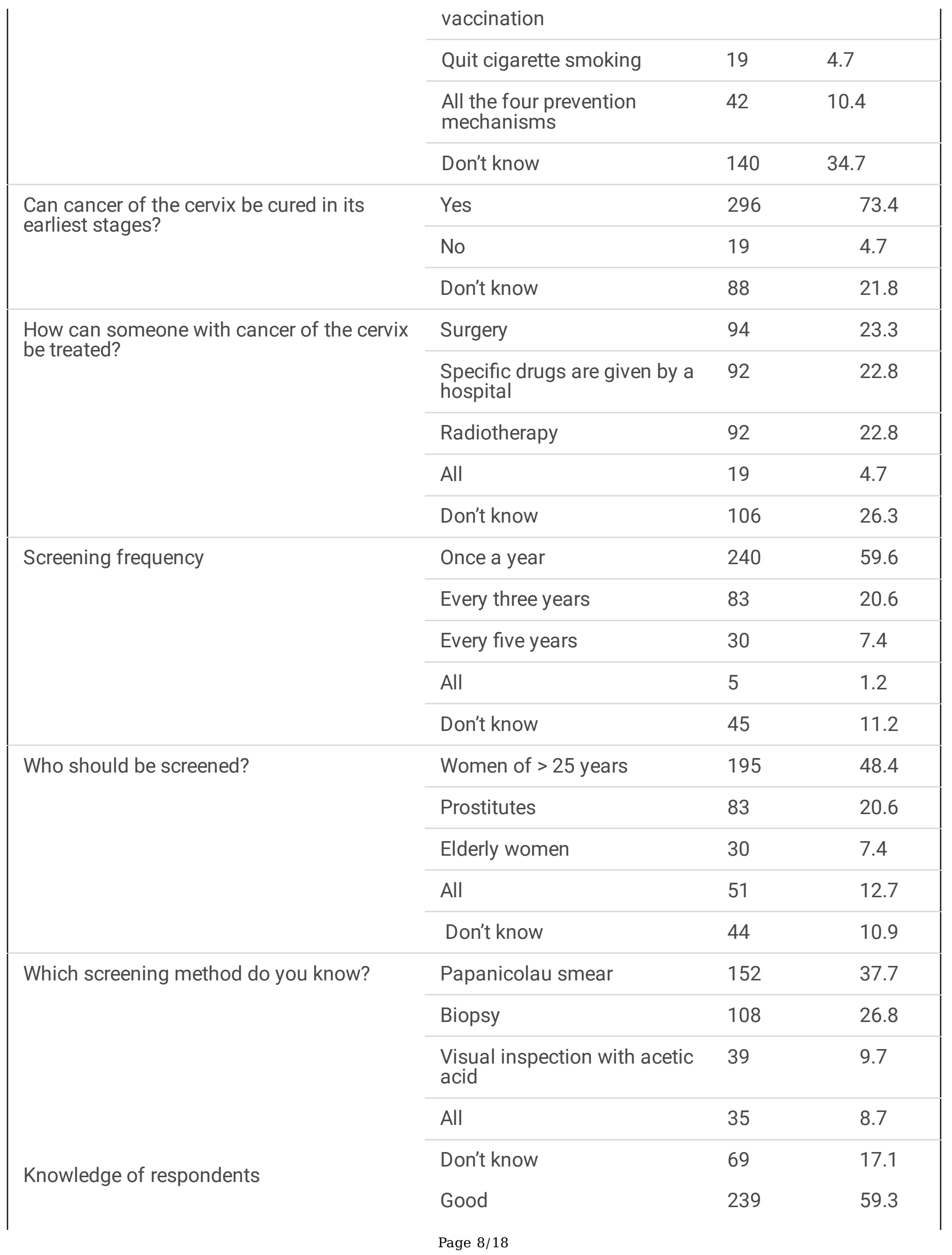




\section{Attitude towards cervical cancer screening, prevention/control}

More than two-thirds of the respondents $273(67.7 \%)$ had a positive attitude, whereas the remaining respondents 130 (32.3\%) had a negative attitude. The majority of the respondents, 361(89.6\%), had a positive attitude towards early detection. Only 229 (56.8\%) of the respondents responded that they have the chance of acquiring cervical cancer. More than one-quarter of the respondents $110(27.3 \%)$ thought that cervical carcinoma is transmitted from person to person. The majority of the respondents 348 (86.4\%) thought that screening helps to prevent cervical cancer (Table 2).

Table 2: Attitudes towards cervical cancer screening, prevention and control, University of Gondar, northwest Ethiopia, April, $2018(n=403)$ 


\begin{tabular}{|c|c|c|c|}
\hline Variables & Categories & Number & $\begin{array}{l}\text { Percent } \\
(\%)\end{array}$ \\
\hline \multirow[t]{5}{*}{ Do you think it is helpful to detect cervical cancer early? } & $\begin{array}{l}\text { Strongly } \\
\text { agree }\end{array}$ & 224 & 61.7 \\
\hline & Agree & 137 & 37.7 \\
\hline & Neutral & 1 & 0.3 \\
\hline & Disagree & 1 & 0.3 \\
\hline & $\begin{array}{l}\text { Strongly } \\
\text { disagree }\end{array}$ & 1 & 0.3 \\
\hline \multirow[t]{5}{*}{$\begin{array}{l}\text { Do you believe that you have the chance of getting Cervical } \\
\text { Cancer? }\end{array}$} & $\begin{array}{l}\text { Strongly } \\
\text { agree }\end{array}$ & 81 & 22.3 \\
\hline & Agree & 148 & 40.8 \\
\hline & Neutral & 8 & 2.2 \\
\hline & Disagree & 106 & 29.2 \\
\hline & $\begin{array}{l}\text { Strongly } \\
\text { disagree }\end{array}$ & 20 & 5.5 \\
\hline \multirow[t]{5}{*}{ believe that getting Cervical Cancer is a serious for } & $\begin{array}{l}\text { Strongly } \\
\text { agree }\end{array}$ & 235 & 64.7 \\
\hline & Agree & 120 & 33.1 \\
\hline & Neutral & 2 & 0.6 \\
\hline & Disagree & 5 & 1.4 \\
\hline & $\begin{array}{l}\text { Strongly } \\
\text { disagree }\end{array}$ & 1 & 0.3 \\
\hline \multirow[t]{5}{*}{$\begin{array}{l}\text { Do you think that there are effective methods to reduce the risk } \\
\text { of seriousness of cervical cancer? }\end{array}$} & $\begin{array}{l}\text { Strongly } \\
\text { agree }\end{array}$ & 150 & 41.3 \\
\hline & Agree & 204 & 56.2 \\
\hline & Neutral & 1 & 0.3 \\
\hline & Disagree & 2 & 0.6 \\
\hline & $\begin{array}{l}\text { Strongly } \\
\text { disagree }\end{array}$ & 6 & 1.7 \\
\hline \multirow[t]{3}{*}{ Do you think Carcinoma of the cervix is the cause of death? } & $\begin{array}{l}\text { Strongly } \\
\text { agree }\end{array}$ & 157 & 43.3 \\
\hline & Agree & 157 & 43.3 \\
\hline & Neutral & 43 & 11.8 \\
\hline
\end{tabular}




\begin{tabular}{|c|c|c|c|}
\hline & Disagree & 3 & 0.8 \\
\hline & $\begin{array}{l}\text { Strongly } \\
\text { disagree }\end{array}$ & 3 & 0.8 \\
\hline \multirow[t]{5}{*}{ Do you think any women acquire cervical cancer? } & $\begin{array}{l}\text { Strongly } \\
\text { agree }\end{array}$ & 254 & 70 \\
\hline & Agree & 87 & 24 \\
\hline & Neutral & 5 & 1.4 \\
\hline & Disagree & 10 & 2.8 \\
\hline & $\begin{array}{l}\text { Strongly } \\
\text { disagree }\end{array}$ & 7 & 1.9 \\
\hline \multirow[t]{5}{*}{ Do you think carcinoma of the cervix can be treated? } & $\begin{array}{l}\text { Strongly } \\
\text { agree }\end{array}$ & 35 & 9.6 \\
\hline & Agree & 75 & 20.7 \\
\hline & Neutral & 94 & 25.9 \\
\hline & Disagree & 131 & 36.1 \\
\hline & $\begin{array}{l}\text { Strongly } \\
\text { disagree }\end{array}$ & 28 & 7.7 \\
\hline \multirow[t]{5}{*}{ Do you think screening helps in preventionof cervical cancer? } & $\begin{array}{l}\text { Strongly } \\
\text { agree }\end{array}$ & 186 & 51.2 \\
\hline & Agree & 162 & 44.6 \\
\hline & Neutral & 3 & 0.8 \\
\hline & Disagree & 9 & 2.5 \\
\hline & $\begin{array}{l}\text { Strongly } \\
\text { disagree }\end{array}$ & 3 & 0.8 \\
\hline \multirow[t]{5}{*}{ Willingness for screening } & $\begin{array}{l}\text { Strongly } \\
\text { agree }\end{array}$ & 100 & 27.5 \\
\hline & Agree & 185 & 51 \\
\hline & Neutral & 30 & 8.3 \\
\hline & Disagree & 39 & 10.7 \\
\hline & $\begin{array}{l}\text { Strongly } \\
\text { disagree }\end{array}$ & 9 & 2.5 \\
\hline \multirow[t]{2}{*}{ Attitude towards Cervical Cancer } & Positive & 273 & 67.7 \\
\hline & Negative & 130 & 32.3 \\
\hline
\end{tabular}




\section{Cervical cancer screening and practices for prevention and control}

Most of the respondents 351(87.1\%) didn't have any sexual experience. Among respondents who had sexual experience, $36(8.2 \%)$ had sexual intercourse at the age of $>18$ years, whereas the smallest proportion of them $16(4 \%)$ had sexual intercourse at the age of $<18$ years.

However, of all the respondents, only $2(0.5 \%)$ of them had been exercised for screening cervical cancer tests. With regard to the reasons why participants were not being screened, 211 (52.4\%) of the respondents indicated that they never had experienced the illness. Among the total respondents, most of the respondents $398(98.8 \%)$ had not vaccinated but only $5(1.2 \%)$ had vaccinated (Table 3$)$.

Table 3: Practice towards cervical cancer screening by undergraduate female students, University of Gondar, Ethiopia, April 2018 ( $n=403)$ 


\begin{tabular}{|c|c|c|c|}
\hline Variables & Category & Number & Percent(\%) \\
\hline \multirow[t]{2}{*}{ Sexual experience } & Yes & 52 & 12.9 \\
\hline & No & 351 & 87.1 \\
\hline \multirow[t]{2}{*}{ Age at the first sex } & $<18$ & 16 & 4 \\
\hline & $\geq 18$ & 36 & 8.9 \\
\hline \multirow[t]{2}{*}{ Number of sexual partners $(n=52)$} & Single & 33 & 8.2 \\
\hline & Multiple & 19 & 4.7 \\
\hline \multirow{2}{*}{$\begin{array}{l}\text { Have you ever screened for cervical } \\
\text { cancer }\end{array}$} & Yes & 2 & 0.5 \\
\hline & No & 401 & 99.5 \\
\hline \multirow[t]{2}{*}{ How many times screened? } & Once & 1 & 0.2 \\
\hline & More than one & 1 & 0.2 \\
\hline \multirow[t]{2}{*}{ When was last time screening? } & Within past three years & 1 & 0.2 \\
\hline & Three years ago & 1 & 0.2 \\
\hline \multirow[t]{4}{*}{ Reason for not screened } & I am healthy & 211 & 52.4 \\
\hline & It may be painful & 55 & 13.6 \\
\hline & I feel shy & 23 & 5.7 \\
\hline & $\begin{array}{l}\text { I'm not informed about screening } \\
\text { place }\end{array}$ & 114 & 28.3 \\
\hline \multirow{2}{*}{$\begin{array}{l}\text { Do you receive a cervical cancer } \\
\text { vaccine? }\end{array}$} & Yes & 5 & 1.2 \\
\hline & No & 398 & 98.8 \\
\hline \multirow{2}{*}{$\begin{array}{l}\text { Have you had a Pap smear done } \\
\text { before? }\end{array}$} & Yes & 2 & 0.5 \\
\hline & No & 401 & 99.5 \\
\hline \multirow[t]{4}{*}{ If not had done, why? } & No time & 45 & 11.2 \\
\hline & Never heard of it & 337 & 83.6 \\
\hline & Partners will not allow & 18 & 4.5 \\
\hline & No interest & 3 & 0.7 \\
\hline
\end{tabular}

\section{Discussion}

From this study, most of the respondents $59.3 \%$ with $95 \% \mathrm{Cl}:(54.3,64.0)$ had good knowledge, which is a little bit higher than a study conducted in Hossana town, Southern, Ethiopia, which is $53.7 \%(13)$. In this 
study, $90 \%$ of the respondents have heard about cervical cancer from different sources, which are comparable with results reported in Sidama zone, southern Ethiopia (92.9\%) (10). However, our finding is higher than findings reported in South Africa, only $42.9 \%$ of the participants have heard about cervical cancer (2). This variation may be due to the educational background of study participants, which is respondents in South African were undergraduate technology students. Of these, who had heard about cervical cancer, nearly one-third of respondents (32.8\%) got this information from their teachers, unlike to findings reported in Uganda, $70.2 \%$ of respondents got information from the radio (14).

More than one-third (35.2\%) of the respondents mentioned that the causative agents of cervical cancer are viruses. This finding is much lower than the results reported in Pakistan, nearly $62 \%$ of the respondents said that viruses are the causative agents of cervical cancer (15). This knowledge variation may come due to the difference in study participants, in which study participants in Pakistan were interns and nurses who are more aware of the disease. But $42.4 \%$ of the respondents did not know about the causative agent. This finding is comparable with $39 \%$ reported by the same study.

More than half of the respondents (52.4\%) knew about the possible sign and symptoms of cervical cancer, which is higher than a report in India, only $36 \%$ of the total participants knew the sign and symptoms (16). This higher result in our study may be due to the fact that the respondents in our study were higher institution students who study health-related courses, unlike the Indian study which is mainly done on adult women in the community who may not have information on cervical cancer sign and symptoms. Among respondents who knew the sign and symptoms, one-fifth of respondents $(20.8 \%)$ were reported vaginal foul-smelling discharge is the symptom of the disease. Similarly, $20.6 \%$ of the respondents reported that irregular vaginal bleeding is the symptom of the disease. A similar study was done in Mizan Tepi University; Southern Ethiopia on female students and $40.67 \%$ and $19.14 \%$ of them mentioned vaginal bleeding and foul-smelling vaginal discharge, respectively. However, half of the respondents (50.72\%) did not know any symptom which is comparable with our findings, (47.6\%) (12).

Avoiding multiple sexual partners and avoiding early sexual intercourse were mostly mentioned prevention methods by the respondents 41.62 and $35.4 \%$, respectively. Unlikely, one-third (33\%) of participants had no idea what risk factors raise the chance of getting cervical cancer. This finding is in line with the results reported in Yemen, 30.5\%(17). In the current finding, among respondents who knew about risk factors, a quarter $(25.1 \%)$ of participants reported that having multiple sexual partners is a risk factor for the disease. This result is in contrast to finding in Yemen (17), 42.3\% of respondents knew about viral infection as a major risk factor for acquiring cervical cancer. More than a quarter $(26.3 \%)$ of the respondents did not know about any treatment options. Among respondents who knew about treatment options, less than a quarter $(23.3 \%)$ of respondents said surgical therapy and $22.8 \%$ chemotherapy. Our findings were a little bit lower than the results reported in Yemen, in which, 35.6\% and $34.1 \%$ of respondents reported surgical treatment and chemical therapy, respectively (17). The majority of the respondents, $(73.4 \%)$ knew early treatment can cure cervical cancer. This result is in line with the result reported in Uganda, $(74.6 \%)$ of respondents knew that the disease was curable if detected early (14). 
The attitude of respondents was also assessed in this study. Majority $(67.7 \%$ with $95 \% \mathrm{Cl}:(63.3,72.0))$ of the respondents had a positive attitude on cervical cancer screening which is supported by a report done on childbearing women in Hossana Town, Hadiya zone, Southern Ethiopia, approximately two-third $(65.2 \%)$ of respondents had a positive attitude (13).Most of the respondents, $89.6 \%$ with $95 \% \mathrm{Cl}$ : 86.6 , 92.3 had a positive attitude towards the importance of early detection of the disease. This finding is a little bit higher than findings reported in Hawassa, Ethiopia, $80.7 \%$ of respondents knew that cervical cancer was curable at an early stage (10).

In this study, more than half of respondents $56.8 \%$ reported that they have the chance of acquiring cervical cancer. Less than three-fourths $(72.7 \%)$ of the respondents thought that cervical carcinoma can be transmitted from person to person. This finding is lower than the result reported in Pakistan (89\%) (15).

Regarding cancer screening, respondents' practice level was assessed. In the study, almost all (99.5\%) of the respondents have poor practice towards cervical cancer screening. This is by far lower than results reported in Tanzania, 22.6\% (18) and Gabon, 65.1\% had done cervical cancer screening (19). This high variation may be due to lack of awareness creation towards cervical cancer screening among students in higher education. Even, the majority of the respondents' family, 95.8\% were not screened for cervical cancer before this study. This evidence showed that the overall screening practice both in the community and among students in Ethiopia was very low. With regard to the reasons why respondents were not being screened, $52.4 \%$ of the respondents indicated that they never had experienced the illness before. This is higher than evidence reported in Mizan Tepi University $36.84 \%$ believed as they were healthy (12). This variation might be due to the common knowledge and understanding difference in relation to cervical cancer. About $28.3 \%$ of respondents indicated that they had never heard about the disease. Among the total respondents, most of them, $98.8 \%$ had not vaccinated and only $1.2 \%$ had vaccinated. This evidence showed that special attention should be given to the prevention of the disease through early vaccination.

Limitation: The results about attitude and practices on screening, prevention, and control of cervical cancer were based on self-reports of participants, which may answer due to social desirability that may result in over or under estimates. The other limitation can be this study was not including all University campus students in the study area.

\section{Conclusion}

Despite the University female students had high proportion of good knowledge and positive attitude, their practices on cervical cancer screening, prevention and control was very low. Thus, there should be an awareness creation on cervical cancer screening for University female students.

\section{Abbreviations}


Cl: Confidence Interval; HPV: Human Papilloma Virus; KAP: Knowledge Attitude and Practice; SD: Standard Deviation; SPSS: Statistical Package for Social Science

\section{Declarations}

\section{Ethics approval and informed consent}

The study protocol was reviewed from Research Ethical Committee in School of Biomedical and Laboratory Sciences, University of Gondar. The study was carried out after obtaining the ethical clearance. The written consent was obtained from each participant. Confidentiality was secured by using anonymous data collection tools. The participants were informed they have a full right to withdraw from the study at any time.

\section{Consent for publication}

Not applicable

\section{Data availability}

The datasets used and/or analyzed during the current study are available from the corresponding author on reasonable request.

\section{Funding}

The source of funding for this research was the principal investigator.

\section{Competing interests}

The authors declare that they have no competing interests.

\section{Acknowledgments}

The authors would like to acknowledge the University of Gondar, College of Medicine, and Health Sciences, School of Biomedical and Laboratory science for their logistic and material support. The authors would also like to thank study participants and facilitators for data collection.

\section{Authors' information}

AG holds BSc degree in Medical Laboratory from Hawassa University and a MScegree in Infectious and Tropical Disease from University of Gondar. TB holds BSc degree in Medical laboratory science from the University of Gondar and Msc degree in diagnostic and public health microbiology from Addis Ababa University. BT holds BSc degree in Medical Laboratory Science and MSc degree in Medical Microbiology from the University of Gondar. 


\section{References}

1. Goodman MT, Shvetsov YB, McDuffie K, Wilkens LR, Zhu X, Franke AA, et al. Hawaii cohort study of serum micronutrient concentrations and clearance of incident oncogenic human papillomavirus infection of the cervix. . Cancer Research. 2007;67(12):5987-96.

2. Hoque $E$, Hoque M. Knowledge and attitude towards cervical cancer among female university students in South Africa. South Afr J Epidemiol Infect. 2009;24(1):21-4.

3. Igwilo Al, Igwilo UU, Hassan F, Idanwekhai M, Igbinomwanhia O, AO P. The Knowledge, Attitude and Practice of the Prevention of Cancer of the Cervix in Okada Community. Asian Journal of Medical Sciences. 2012;4(3):95-8.

4. Oche MO, Kaoje UM, Gana G, JT A. Cancer of the cervix and cervical screening Current knowledge, attitude and practices of female health workers in Sokoto, Nigeria. International Journal of Medicine and Medical Sciences 2013;5(4):184-90.

5. Wright KO, Aiyedehin O, Akinyinka MR, O I. Cervical Cancer: Community Perception and Preventive Practices in an Urban Neighborhood of Lagos, Nigeria. Preventive Medicine. 2014;2:1-9.

6. Ibrahim U. Assessment of Cervical Cancer Knowledge, Perception and Preven-tion Attitude among Female Students Of Reproductive Age (16-49) In Four Tertiary Institution Within Bauchi Metropolis. International Journal of Advancements in Research \& Technology. 2014;3(11):1-6.

7. Torre LA, Bray F, Siegel RL, Ferlay J, Lortet-Tieulent J, A J. Global cancer statistics, 2012. CA Cancer J Clin. 2015;65(2):87-108.

8. FMOH. National Strategic Action Plan (NSAP) for prevention \& control of non communicable diseases in Ethiopia from 2014-2016.

9. WHO(2008). HPV Information Centre. Human Papilloma virus and related cancers, summary report update.

10. Dulla D, Daka D, Wakgari N. Knowledge about cervical cancer screening and its practice among female health care workers in southern Ethiopia: a cross-sectional study. International journal of women's health. 2017;9:365.

11. Gultie A, Sahile S, C S. Assessment of fruit management in Gondar town market of Northwestern Ethiopia. GJBAHS. 2013;2 (4):4-8.

12. Mulatu K, Motma A, Seid M, M T. Assessment of Knowledge, Attitude and Practice on Cervical Cancer Screening among Female Students of MizanTepi University, Ethiopia. ; . 2017;1:1. . Cancer biology and therapeutic oncology. 2016;1:1.

13. Aweke YH, Ayanto SY, TL E. Knowledge, attitude and practice for cervical cancer prevention and control among women of childbearing age in Hosanna Town, Hadiya zone, Southern Ethiopia. . PLoS ONE. 2017;12(7):e0181415.

14. Mukama T, Ndejjo R, Musabyimana A, Halage AA, D M. Women's knowledge and attitudes towards cervical cancer prevention. ; . BMC Women's Health 2017;17:9. 
15. Ali SF, Ayub S, Manzoor NF, Azim S, Afif M, Akhtar N, et al. Knowledge and Awareness about Cervical Cancer and Its Prevention amongst Interns and Nursing Staff in Tertiary Care Hospitals in Karachi, Pakistan. PLoS ONE. 2010;5 (6):1-6.

16. Bansal AB, Pakhare AP, Kapoor N, Mehrotra R, AM K. Knowledge, attitude, and practices related to cervical cancer among adult women: A hospital-based cross-sectional study. Journal of Natural Science, Biology and Medicine. 2015;6(2):324-8.

17. Abdul-Aziz M. Knowledge, attitude and practice towards cervical cancer among reproductive health clients at the University of Science \& Technology Hospital-Sana'a in Yemen. Yemeni Journal for Medical Sciences. 2012;6.

18. Lyimo FS, TN B. Demographic, knowledge, attitudinal, and accessibility factors associated with uptake of cervical cancer screening among women in a rural District of Tanzania. BMC Public Health. 2012;12:22.

19. Assoumou SZ, Mabika BM, Mbiguino AN, Mouallif M, Khattabi A, MM E. Awareness and knowledge regarding of cervical cancer, Pap smear screening and human papillomavirus infection in Gabonese women. BMC Women's Health. 2015;15:37. 